\title{
Corporate Criminal Sanctions in the Crime of Forest Destruction with a Restorative Justice Approach
}

\author{
Agus Suciptoroso ${ }^{1}$, Andi Muhammad Sofyan ${ }^{2}$, Winner Sitorus ${ }^{3}$ Kahar Lahae ${ }^{4}$ \\ 1,2,3,4 Faculty of Law, Hasanuddin University, \\ Makassar, Indonesia \\ agussuciptoroso@gmail.com
}

\begin{abstract}
Forests are national treasures that must be protected by anyone without exception. Today many forests are reduced due to destruction by humans and corporations. This study examines the Corporate Criminal Sanctions in the Crime of Forest Destruction with a Restorative Justice Approach. The legal issues in the research are, first, what are the sanctions for corporations that are currently destroying forests and second how to punish corporations in the crime of forest destruction with a restorative justice approach as an optimization effort to restore forest conditions. The method used is a normative juridical research method, namely research on legal principles using secondary data. While the data analysis method used is a qualitative method and the data collection tool used is the study of documents. The result of this study, first, Sanctions for corporations that commit crimes against forest destruction currently consist of criminal sanctions and administrative sanctions. Criminal sanctions include imprisonment, fines, and additional penalties, namely replacement money. Meanwhile, the administrative sanctions as stipulated in Law Number 11 of 2020 concerning Job Creation are regulated as follows: a. written warning; b. government coercion; c. administrative fines; $d$. freezing of Business Licensing; and $f$ or e. revocation of Business License. Second, Sentencing with the concept of restorative justice needs to be considered in the future, this is to evaluate the weaknesses of the retributive justice approach. Restorative justice focuses on how a criminal liability can provide a solution for forest restoration and compensation to the state.
\end{abstract}

Keywords- Corporation, Sanctions, Restorative Justice.

\section{INTRODUCTION}

Forest resources have an important role in providing industrial raw materials, sources of income, creating jobs and opportunities. Forest products are commodities that can be converted into processed products in an effort to get added value and open up job opportunities and business opportunities. Forest utilization is not limited to production of wood and non-timber forest products, but must be expanded with other uses such as germplasm and environmental services, so that forest benefits are more optimal [1].

The efforts of the Indonesian state to protect forest areas in the context of forest utilization are generally regulated in the Forestry Law (Law Number 41 of 1999 concerning Forestry as amended by Law Number 19 of 2004 concerning Stipulation of Government Regulations in Lieu of Law Number 1 of 2004 concerning
Amendments to Law No. - Law Number 41 of 1999 concerning Forestry) and Law Number 18 of 2013 concerning Prevention and Eradication of Forest Destruction, and most recently Law Number 11 of 2020 concerning Job Creation.

Forest utilization often includes actions that can damage forest areas, whether carried out by individuals or corporations. Recently, forest destruction has become more widespread and complex. Forest destruction does not only occur in production forest areas but also penetrates into protected forests.

The current condition of the forest is very concerning, which is marked by the increasing rate of forest degradation, underdevelopment of investment in the forestry sector, low progress of plantation forest development, lack of control over forest crimes, the decline in the economy of communities in and around the forest, and the increasing area of forest areas that are not properly managed. so that strategic efforts need to be made in the form of deregulation and debureaucratization[2].

Forest damage originating from forest fires lately often occurs, both openly and secretly, the perpetrators of these forest fires are various, both individuals and corporations. In 2019, the Ministry of Environment and Forestry investigated at least 5 other companies and sealed 51 companies, along with 1 individual owned, with a total land area of 8,931 hectares [3].

The development of the rules of Indonesian criminal law, corporations can be burdened with criminal liability or can be said to be the subject of criminal law. Corporations really exist and occupy an important position in our society and are capable of causing harm to others in society as well as humans. Treating corporations like humans (natural persons) and burdening them with liability for criminal acts committed by corporations, is in line with the legal principle that everyone is equal before the law (principle of equality before the law) [4].

Placing corporations as the subject of criminal acts will provide hope and optimism for efforts to investigate corruption as thoroughly and effectively as possible [5]. Corporations as the subject of criminal acts are not new, however, according to Muladi and Dwidja Priyatno, the law enforcement process is still very slow [6]. 
Crimes committed by corporations in the forest sector arise from deviant corporate goals and interests in relation to their role in the utilization and management of forest resources, industrial activities by utilizing advanced science and technology to achieve development targets in the economic sector, thereby placing forests as objects. commodity and can be exploited for the purposes and interests of profit.

Considering that corporate crimes in the forestry sector can have a large and complex impact, where not only the Indonesian people and nation are victims, but other communities and countries are also victims, it is necessary to have serious and serious efforts in enforcing the rule of law against violators who destroy the forest. One of the efforts to tackle corporate crime in the forestry sector is to use criminal law, namely through criminal law policies.

It is undeniable that the punishment of corporations that prioritizes a retributive justice approach will have more negative impacts, especially on people who depend on corporations for their lives. This dilemmatic problem is an obstacle in law enforcement against corporations [7]. This is because the activities carried out by corporations are related to economic stability and national development. In addition, it also considers the social impact caused by corporate punishment which can actually cause crises in various fields [8].

Retributive justice, which emphasizes retaliation, certainly has an adverse effect on victims, especially the forest because it cannot restore the condition of the forest to its original state. It is difficult to restore forest conditions to return to their original state, one way is a restorative justice approach. This approach emphasizes the realization of justice and balance for the perpetrators of criminal acts with their victims in this case the forest.

The restorative justice approach is marked by a change in principles in eradicating criminal acts of forest destruction from primum remedium to ultimum remedium. The means of administrative sanctions regulated in the forest destruction law are not able to tackle corporate crimes and the resulting forest restoration. The use of a restorative justice approach is expected to be able to restore the original situation. Therefore, it is interesting to study what are the sanctions for corporations that are currently destroying forests? And how is corporate punishment in the crime of forest destruction with a Restorative Justice approach as an optimization effort to restore forest conditions?

\section{RESEARCH METHOD}

Form of this research is juridical normative, namely by examining written legal norms directly on the subject matter which is the subject of this research. The data used in this study, namely secondary data that is not obtained directly from the field but through the process of searching for library materials, and in the form of secondary legal material in the form of theories taken from various literature works, the 1945 Constitution of the Republic of Indonesia and laws and regulations.

Researchers used data collection tools in the form of document studies and theories and existing regulations. The data analysis method used in processing the data related to this research is a qualitative method because data processing is not done by measuring the secondary data related to it, but descriptively analyzing the data. In a qualitative approach, research procedures produce descriptive analytical data.

\section{FINDINGS AND DISCUSSION}

\section{Sanctions for corporations that are currently destroying forests.}

Etymologically the word corporation (Dutch: corpotatie, English: Corporation, German: korporation) comes from the Latin word "corporatio". As is the case with other words that end in "tio" then "corporatio" as a noun (substantivum), comes from the verb "corporare" which was widely used by people in the Middle Ages or after that. Corporare itself comes from the word "corpus" (Indonesian = body), which means to give a body or make up. Thus "corporatio" means the result of physical work, in other words a body made into a person, a body obtained by human actions as opposed to the human body, which occurs according to nature [10].

Forest damage can result in a decrease in economic benefits, but also affects other sectors that need water, forest damage triggers natural disasters, and can reduce the quality of the local, national and global environment.

Deforestation is increasingly widespread and complex. The destruction occurred not only in production forests, but also in protected forests or conservation forests. Deforestation has developed into a crime that has extraordinary impacts and is organized and involves many parties, both national and international. The damage caused has reached a very worrying level for the survival of the nation and state. Therefore, the handling of forest destruction must be carried out in an extraordinary manner [11].

Forests are not only a priority by the Government of Indonesia but also internationally, considering that forests are the lungs of the world that function for the continuity of healthy life. Therefore, corporations or business entities in carrying out forest-related business activities burn land because the impact of forest fires can damage ecosystems and destroy plants and animals, as well as pollute the environment with smoke that can interfere with the health of Indonesian people and even the international world. 
Regulations governing forests have long been regulated in Indonesia, criminal acts of destruction are regulated in Law Number 5 of 1967 concerning Basic Provisions of Forestry, Law no. 41 of 1999 concerning Forestry, Law Number 18 of 2013 concerning Prevention and Eradication of Forest Destruction, and Law Number 11 of 2020 concerning Job Creation.

History records that Law No. 5/1967 on the Principles of Forestry consists of 21 articles. The criminal provisions in this law are contained in Article 19 paragraph (1) which reads "The implementing regulations of this law may contain criminal sanctions in the form of imprisonment or confinement and/or fines". One of the implementing regulations for this Law is the Government Regulation of the Republic of Indonesia Number 28 of 1985 concerning Forest Protection.

The subject of criminal acts in the Government Regulation of the Republic of Indonesia Number 28 of 1985 concerning Forest Protection is only people, this can be seen from the criminal provisions in Article 18 which emphasizes who, where anyone refers to the Criminal Code, namely only people. The sanctions imposed in this government regulation are imprisonment and fines. Corporations in this implementing regulation have not been regulated either as legal subjects or sanctions.

Law Number 41 of 1999 concerning Forestry regulates corporations as legal subjects with the designation of legal entities or business entities. Everyone referred to in Article 50 paragraph (1) of Law Number 41 of 1999 is a legal subject, whether it is an individual, a legal entity, or a business entity. Legal entities in question include limited liability companies, limited liability companies (comanditer venootschaap), firms, cooperatives, and the like (Article 78 paragraph 14 of Law Number 41 of 1999).

Article 78 paragraph (14) of the Forestry Law regulates: "Criminal acts as referred to in Article 50 paragraph (1), paragraph (2), paragraph (3) if committed by and or on behalf of a legal entity or business entity, prosecution and the criminal sanctions imposed on the management, either individually or jointly, are subject to criminal sanctions in accordance with the respective criminal threats plus $1 / 3$ (one third) of the sentence imposed [13].

Law Number 18 of 2013 regulates criminal acts against corporations, the authors can summarize as follows: 1) Article 82 paragraph (3), 2) Article 83 paragraph (4), 3) Article 84 paragraph (4), 4) Article 85 paragraph (2), 5) Article 86 paragraph (2), 6). Article 87 paragraph (4), 7) Article 88 paragraph $(2), 8)$ Article 89 paragraph (2), 9) Article 90 paragraph (2), 10) Article 91 paragraph (2), 11) Article 92 paragraph (2 ), 12) Article 93 paragraph (3), 13) Article 94 paragraph (2), 14) Article 95 paragraph (3), 15) Article 96 paragraph (2), 16) Article 97 paragraph (3), 17) Article 98 paragraph (3), 18) Article
99 paragraph (3), 19) Article 100 paragraph (2), 20) Article 101 paragraph (3), 21) Article 102 paragraph (2) Article 103 paragraph (2) [14].

The criminal provisions against corporations are very different from the criminal provisions against corporations as stipulated in Law No. 41 of 1999 concerning Forestry, where in Law No. 41 of 1999 it has not separately stated criminal provisions against corporations. The criminal provisions against corporations based on Law No. 18 of 2013 related to the purpose of the law are to ensure legal certainty and provide a deterrent effect for perpetrators of forest destruction and to ensure the existence of forests in a sustainable manner while maintaining sustainability and not damaging the environment and surrounding ecosystems.

In providing a deterrent effect for perpetrators of forest destruction by corporations, Law No. 18 of 2013 has regulated sanctions, namely criminal sanctions and administrative sanctions. Criminal sanctions in the form of imprisonment, fines, additional penalties, namely replacement money. Meanwhile, the administrative sanctions as regulated in Article 18 paragraph (1) can be in the form of government coercion, forced money and or revocation of permits. The sanctions were later amended through Law Number 11 of 2020 concerning Job Creation which is regulated as follows: corporations are subject to administrative sanctions in the form of: a. written warning; b. government coercion; c. administrative fines; d. freezing of Business Licensing; and $f$ or e. revocation of Business License.

\section{Restorative Justice Approach as an Optimization Effort to Restore Forest Conditions.}

Criminal sanctions are given to everyone who commits a violation or crime, both individuals and corporations. Criminal law is the domain of public law, so the state has the right to intervene. The emphasis on criminal imposition is on giving sorrow to people who commit violations or crimes. The settlement of criminal cases does not have to use criminal justice facilities. The expected goal of imposing criminal sanctions is legal justice.

The concept of restorative justice has actually been raised for a long time to improve the criminal system both in the international world and in Indonesia itself. Long before this concept was born, restorative justice has existed in the midst of Indonesian people's lives [15].

The advantages that can be obtained from the application of restorative justice to the criminal justice system are as follows: [16] a) The restorative justice approach provides alternatives for handling criminal acts by providing space for the achievement of an out of court settlement within the scope of criminal law. b) Eliminating the process of prosecution and trial which will take a long time will greatly help reduce arrears in 
cases and at the same time reduce the burden of enormous costs. c) The imposition of a prison sentence can have a negative impact because as people in a community institution when they leave, they are not more aware but even more evil because while in prison they usually meet other criminals and have a crime school study room. d) Avoiding the burden of excess occupants against prison capacity. e) Savings in the state financial budget so that it can be used for other important purposes.

Muladi stated that: [17] "Considering that the impact of punishment on corporate crimes is very broad, both in terms of being a source of state tax revenue, the fate of employees, the fate of consumers and shareholders and so on, there is an opinion that criminal law should be applied as an ultimum remedium, among others by utilizing "restorative justice". "not as Primum remedium".

Based on Muladi's opinion, criminal sanctions are given to corporations when other sanctions are unable to cope. Before the means of criminal law are used, other means are used, such as means of civil law and administrative law, settlements outside the judicial process, so that criminal law is used as a means of second choice.

Based on comparative studies in various countries, it shows that the sanctions that can be imposed on corporations vary in form, including: [18]. Financial fines or sanctions, for example prohibition of issuing checks (pecuniary penalties); $\mathrm{b}$. confiscation of the proceeds of crime; c. Takeover; d. Temporarily or permanently closing the building used to commit the crime; e. Temporary or permanent company closure; f. Temporary or permanent license revocation; g. Administrative action, placed under a temporary court-appointed administrator; h. Announcement of judge's decision; i. Temporarily prohibits from carrying out certain actions such as temporary or permanent prohibition from contracting with the government or other public institutions; j. Restoration orders, in the form of orders to do what the corporation has neglected or not to do what the corporation has done against the law; k. Supervision (mandatory management oversight, probation); and 1. Criminal social work (community service order).

Placing corporations as subjects of criminal law, in criminalizing corporations, of course, refers to the ideals of reform. Law enforcement against corporations not only prioritizes legal certainty but also social justice, especially the affected community and the environment.

Reform of standard regulations in dealing with corporate crime (in general) in the future needs to be strengthened and includes: [19]. a) Nationally, the regulation and formulation must have a uniform and consistent pattern; b) The scope and understanding of the meaning of the corporation must be clear; c) The definition of every person in a criminal act must be clearly stated as including a corporation; d) It must be clarified whether the function of criminal law is "ultimum remedium" or "primum remedium" e) It must be clearly specified the difference between criminal law sanctions in the form of criminal acts and actions with administrative legal sanctions; f) Procedural law dealing with corporate crimes must be clear, including the standard of evidence; g) The requirements for the extent to which corporations can be accounted for must be formulated properly to serve as guidelines for law enforcement; h) The scope of criminal liability in relation to the types of criminal acts that are excluded, participation in excluded criminal acts, participation in excluded criminal acts and aggravating and mitigating matters must be emphasized; and i) Attention to victims (restitution) and whistleblowers.

The concept of restorative justice offers a model for resolving cases outside the existing criminal justice process. Currently, the Indonesian Restorative Justice concept has been adopted in the Draft Criminal Code (RKUHP), the latest version of which is September 2019, including:

Article 56 of the Draft Criminal Code states that in sentencing a corporation, it is obligatory to consider: a. the level of loss or impact caused; b. the level of involvement of the management who has the functional position of the Corporation and/or the role of giving orders, controlling holders, giving orders, and/or beneficial owners of the Corporation; c. the length of the crime that has been committed; $d$. frequency of Criminal Acts by Corporations; e. form of criminal offense; $f$. official involvement; g. the values of law and justice that live in society; h. the track record of the Corporation in conducting business or activities; $i$. the effect of punishment on the Corporation; and/or j. Corporate cooperation in handling criminal acts.

Article 51 letter $\mathrm{C}$ of the Criminal Code Bill aims to resolve conflicts caused by criminal acts, restore balance, and bring a sense of security and peace in society.

Article 53 of the Draft Criminal Code states: (1) "In adjudicating a criminal case, the judge is obliged to uphold law and justice. (2) If in upholding law and justice as referred to in paragraph (1) there is a conflict between legal certainty and justice, the judge is obliged to prioritize justice.

The Draft Criminal Code regulates the considerations before the sentence is imposed, namely in Article 54 paragraph (1) letter h. criminal influence on the future of the perpetrators of the crime; i. the influence of the Crime on the Victim or the Victim's family; $j$. forgiveness from the Victim and/or his family; and/or k. values of law and justice that live in society.

Article 120 paragraph (1) additional penalties for corporations as referred to in Article 118 letter b consist of: b. repairs due to criminal acts. 
Article 120 paragraph (1) of the Draft Criminal Code states that additional penalties for corporations as referred to in Article 118 letter b consist of: b. repairs due to criminal acts.

Article 132 paragraph (1) of the Draft Criminal Code states that the prosecution authority is declared null and void if: a. there has been a court decision that has permanent legal force against a person in the same case; b. the suspect or defendant dies; c. expired; d. maximum fines are paid voluntarily for criminal acts which are only threatened with a maximum fine of category III; e. a maximum fine of category IV is paid voluntarily for a crime punishable by a maximum imprisonment of 1 (one) year; f. withdrawal of a complaint for a criminal offense; or g. regulated in the Act. (2) The provisions regarding the loss of prosecution authority for corporations are the same as those for individuals with due observance of the provisions as referred to in Article 121.

The articles in the Draft Criminal Code have basically adapted the concept of restorative justice which emphasizes the realization of justice and legal balance for perpetrators of criminal acts and victims of criminal acts properly, without the imposition of criminal sanctions.

Based on this description, the settlement of cases whose legal subjects are corporations in criminal acts of forest destruction by restorative justice, needs to be accommodated to reduce the weaknesses of the retributive justice approach as regulated in Law Number 18 of 2013 as it has been applied so far. Restorative justice, which focuses on accountability for legal actions, provides another alternative that is fair in principle for all parties (win-win solution) to restore the situation so that it is as before and compensation to victims, in this case humans and nature. In addition, the restorative justice approach aims to create better forest conditions in the future.

\section{IV.CONCLUSION}

Sanctions for corporations that commit criminal acts of forest destruction currently consist of criminal sanctions and administrative sanctions. Criminal sanctions include imprisonment, fines, and additional penalties, namely replacement money. Meanwhile, administrative sanctions as regulated in Law Number 11 of 2020 concerning Job Creation are regulated as follows: a. written warning; B. government coercion; C. administrative fines; D. freezing of Business Licensing; and for E. revocation of Business License. Second, punishment with the concept of restorative justice needs to be considered in the future, this is to evaluate the weaknesses of the retributive justice approach. Restorative justice focuses on how criminal liability can provide solutions for forest restoration and compensation to the state.

\section{REFERENCES}

[1] Elucidation of Law Number 41 of 1999 concerning Forestry.

[2] Ediwarman, Penegakan Hukum Pidana Dalam Perspektif
Kriminologi. Yogyakarta : Genta Publishing, 2014.

[3] https://fokus.tempo.co/read/1249811/perorangan-to-korporasijadi-tersangka-case-kebakaran-hutan accessed on August 16, 2021

[4] Erdiansyah dalam "Implementasi Pertanggungjawaban Pidana Korporasi Pembakaran Hutan Dan Lahan Di Provinsi Riau”, Jurnal Ilmu Hukum, Volume 4 No. 3 September 2014-Januari 2015.

[5] Widodo Tresno Novianto dalam "Korporasi Sebagai Subyek Tindak Pidana Korupsi dan Prospeknya Bagi Penanggulangan Korupsi Di Indonesia", Yustisia, Edisi Nomor 70 Januari-April 2007.

[6] Muladi dan Dwidja Priyatno, Pertanggungjawaban Pidana Korporasi, Edisi Revisi, Kencana Prenadamedia Group, Jakarta, 2010

[7] Pujiyono dalam Pujiyono, Nur Rochaeti, Adi Bayu Airlangga, Pertanggungjawaban Pidana Korporasi Melalui Konsep Restorative Justice, Pembaharuan Hukum Pidana Vol. 2 No. 2 Sep 2019.

[8] Ibid.

[9] Soetan K Malikoel Adil, dalam Muladi dan Dwidja Priyatno, Pertanggungjawaban Pidana Korporasi Dalam Hukum Pidana, Cetakan Keempat, Jakarta : Kencana Prenandamedia Group, 2013.

[10] ibid.

[11] General Explanation of Law Number 18 of 2013 concerning Prevention and Eradication of Forest Destruction.

[12] Law Number 5 of 1967 concerning the Principles of Forestry.

[13] Law Number 41 of 1999 on Forestry

[14] Law Number 18 of 2013 concerning Prevention and Eradication of Forest Destruction

[15] Prayogo Kurnia, Resti Dian Luthviati, Restika Prahanela, "Penegakan Hukum Melalui Restorative Justice Yang Ideal Sebagai Upaya Perlindungan Saksi Dan Korban”, GEMA, Th. XXVII/49/Agustus 2014 - Januari 2015.

[16] Herlyanty Yuliana Anggraeny Bawole, Implementasi Restoratif Dalam Penanggulangan Kejahatan Korporasi Menurut Sistem Hukum Pidana di Indonesia, Lex Crimen Vol. III/No. 3 (Jakarta, 2014)

[17] P. P. Pujiyono, and R. D. Susanti, "Alternatif Model Pertanggungjawaban Pidana Korporasi Melalui Pendekatan Keadilan Restoratif," Pembaharuan Hukum Pidana, vol. 2, no. 2, Aug. 2019.

[18] Muladi dan Diah Sulistyani, Pertanggungjawaban Pidana Korporasi (Corporate Criminal Responsibility), Edisi Kedua Cetakan Pertama, Bandung: Alumni, 2015.

[19] Muladi dan Diah Sulistyani, Pertanggungjawaban Pidana Korporasi (corporate Criminal Responsibility), Bandung : Alumni, 2013 